\title{
Aortic valve involvement and premature coronary artery disease in Heterozygous Familial Hypercholesterolemia
}

\section{Heterozigot Ailevi Hiperkolesterolemide aort kapă̆ı tutulumu ve erken koroner arter hastalı̆̆ı}

\author{
Hakkı Şimşek ${ }^{1}$, Mustafa Tuncer ${ }^{2}$, Musa Şahin ${ }^{2}$, Hasan Ali Gümrükçüoğlu ${ }^{2}$, Beyhan Eryonucu ${ }^{3}$ \\ ${ }^{1}$ Osmaniye State Hospital, Cardiology Department, Osmaniye, Turkey \\ 2 Yüzüncü Yıl University, Faculty of Medicine, Cardiology Department, Van, Turkey \\ ${ }^{3}$ Fatih University, Faculty of Medicine, Cardiology Department, Ankara, Turkey
}

\begin{abstract}
Familial hypercholesterolemia $(\mathrm{FH})$ is an autosomal dominant disorder characterized by an elevation of LDL cholesterol concentration in plasma leading to deposition of excess LDL-derived cholesterol in tendons, skin and arteries. We studied a 34 year old woman who applied to dermatology department due to multiple xanthomas. Cardiac consulting was demanded by dermatology department to determine development of atherosclerosis. Patient had no risk factor and symptom related to cardiac problem, except family history included premature coronary artery disease (CAD). On examination systolic murmur was present in aortic area. Echocardiography showed valvular severe aortic stenosis with a good left ventricle systolic function and severe left ventricular hypertrophy. The coronary arteriogram showed widespread CAD involving 3 coronary vessels. We report a case of heterozygous $\mathrm{FH}$ type II a with premature CAD and aortic valve involvement. J Clin Exp Invest 2011; 2 (3): 308-311.
\end{abstract}

Key words: Aortic stenosis, Coronary artery disease, Heterozygous familial hypercholesterolemia

\section{INTRODUCTION}

Familial hypercholesterolemia (FH) is a common autosomal dominant disorder caused by a mutation of the gene for the low-density lipoprotein (LDL) receptor. ${ }^{1} \mathrm{FH}$ is usually a manifestation of increased levels of LDL cholesterol. Triglyceride levels are usually normal (type II a) or may be elevated (type $\mathrm{IIb})$. Heterozygous FH (HeFH) (1:500) more frequent than homozygous FH (HoFH) (1:1 000 000) in general population. ${ }^{2} \mathrm{FH}$ is characterized by a high level of dominantly inherited hypercholesterolemia, early appearance of cutaneous and tendon

\section{ÖZET}

Ailesel hiperkolesterolemi $(\mathrm{AH})$ arterlerde, ciltte ve tendonlarda aşırı kolesterol birikimine yol açan plazma kolesterol yüksekliği ile karakterize otozomal dominant bir hastalıktır. Multipl ksantomlar nedeniyle cildiye polikliniğine başvuran 34 yaşında bayan hasta için aterosklerotik hastalık açısından kardiyoloji konsültasyonu istendi. Hastanın herhangi bir kardiyak şikayeti yoktu. Koroner arter hastalığı (KAH) açısından risk faktörü olarak ailede erken $\mathrm{KAH}$ öyküsü mevcuttu. Fizik muayenede aort odakta 3/6 sistolik üfürüm saptandı. Yapılan ekokardiyografide ciddi aort darlığı saptandı. Yapılan koroner anjiografide 3 koroner damarın etkilendiği yaygın $\mathrm{KAH}$ saptandı. Biz bu yazıda aort kapak tututulumu ve erken yaşta $\mathrm{KAH}$ nın eşlik ettiği heterozigos AH vakasını sunduk. Klin Deney Ar Derg 2011; 2 (3): 308-311.

Anahtar kelimeler: Aort stenozu, koroner arter hastalığı, heterozigoz ailesel hiperlipidemi

xanthomata, and increased risk of premature coronary artery disease (CAD). Approximately $85 \%$ of males and $50 \%$ females of suffer from coronary events before 65 years old if they are not treated. ${ }^{3}$ The rate of death from $\mathrm{CAD}$ among $\mathrm{HeFH}$ patients is several times higher than that among the general population. ${ }^{4}$ Hyper cholesterolemi affects not only the coronary artery, but also cardiac valve especially aortic valve and aortic root. Hyperlipidemia is associated with degenerative aortic valve stenosis, and the disease resembles the inflammatory process of atherosclerosis. ${ }^{5}$ Hypercholesterolemia constitute

\section{Yazışma Adresi /Correspondence: Dr. Musa Şahin}

Yüzüncü Yıl University, Faculty of Medicine, Cardiology Department, Van, Turkey Email: drmusasahin@gmail.com Geliş Tarihi / Received: 18.01.2011, Kabul Tarihi / Accepted:12.03.2011

Copyright (C Klinik ve Deneysel Araştırmalar Dergisi 2011, Her hakkı saklıdır / All rights reserved 
an important factor for etyologies of aortic stenosis in adult patients. We report a case of HeFH type II a with concomitant aortic stenosis and coronary artery disease involving three vessels.

\section{CASE}

A 34 year old female patient applied to dermatology department due to xanthomata. Cutaneous examination of the case revealed multiple eruptive yellowish papules on the eyelids, trunk, and limbs. There were a few nodules covering the ankle joints and feet of patient. Yellowish papules were detected on the interdigital web space of the fingers (Figure 1). Mucosa, hair and nails were normal. Although the patient had no symptom related to cardiac problem cardiac consulting was demanded by dermatology department to determine development of atherosclerosis. The patient had no risk factors for cardiovascular disease except family history including death of her brother due to cardiac problem at the age of 30 during operation making for removal of multiple xanthomas and her father and uncle had coronary arter disease. However, her mother and other siblings didn't have hyperlipidemia, thereby indicating $\mathrm{HeFH}$ in this patient. The patient's blood pressure was 120/70 and pulse rate was regular (96 beats/min). On cardiac examination, a systolic ejection murmur was heard in aortic area. Electrocardiography (ECG) revealed normal sinus rhythm. Total cholesterol, triglyceride, HDL and LDL values were 493, 121, 24, and $442 \mathrm{mg} / \mathrm{dL}$, respectively. Echocardiography demonstrated left ventricle hypertrophy with normal systolic function, calcified and degenerative aortic valve with limited opening and $44 \mathrm{~mm} \mathrm{Hg}$ mean gradient across the aortic valve (Figure 2). Aortic valve area was $1.2 \mathrm{~cm}^{2}$. The mitral valve was looked high-echogenic and thickened but gradient was not obtained. Coronary anjiography detected $60 \%$ occlusion at the proximal to Left Anterior Desending (LAD) before D1 branch, 40\% occlusion at LAD mid-portion, $40 \%$ occlusion at Circumflex artery (Cx) mid-portion, and $100 \%$ occlusion proximal to Right Coronary Artery (RCA). Retrograde flow of RCA was also present from $\mathrm{Cx}$ artery. Medical therapy was initiated for prevention of secondary coronary arter dissease and progretion of aortic stenosis.. Hypercholesterolemia was managed with atorvastatin $80 \mathrm{mg}$ per day. Because the patient had no symptom related to cardiac problem routine follow-up was advised.

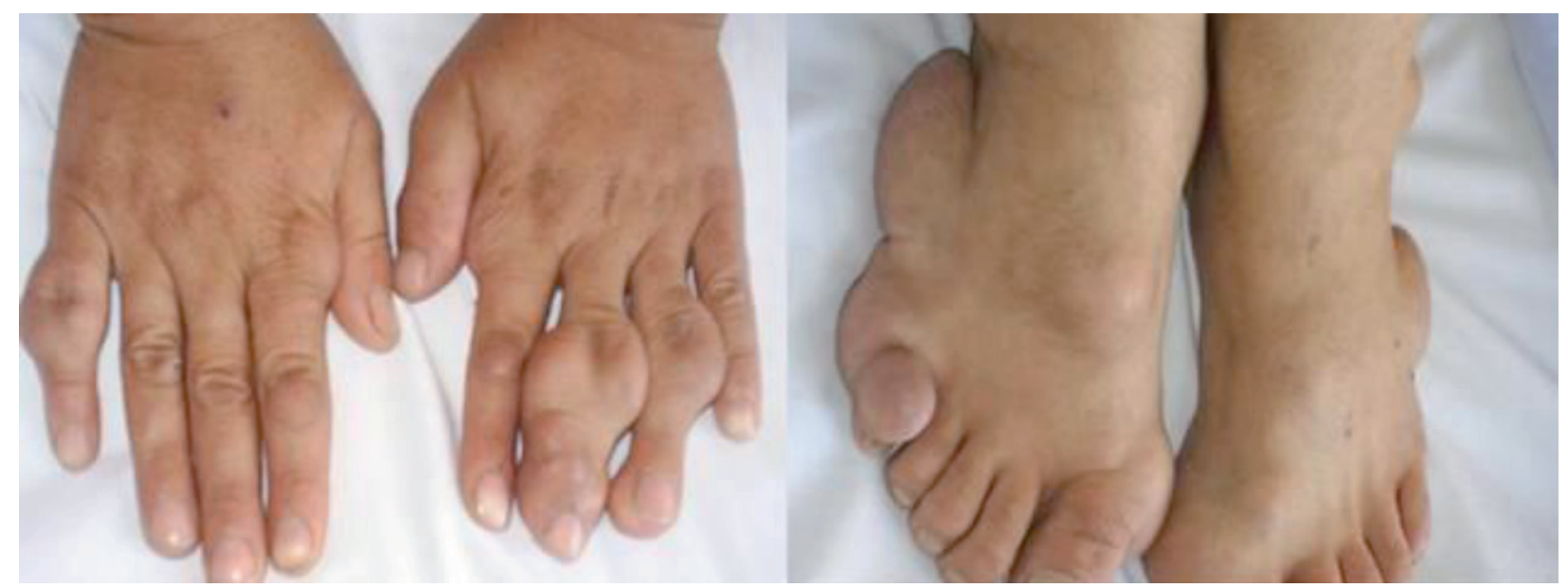

Figure 1. Multiple xanthomata showed on fingers of hand and foot. 


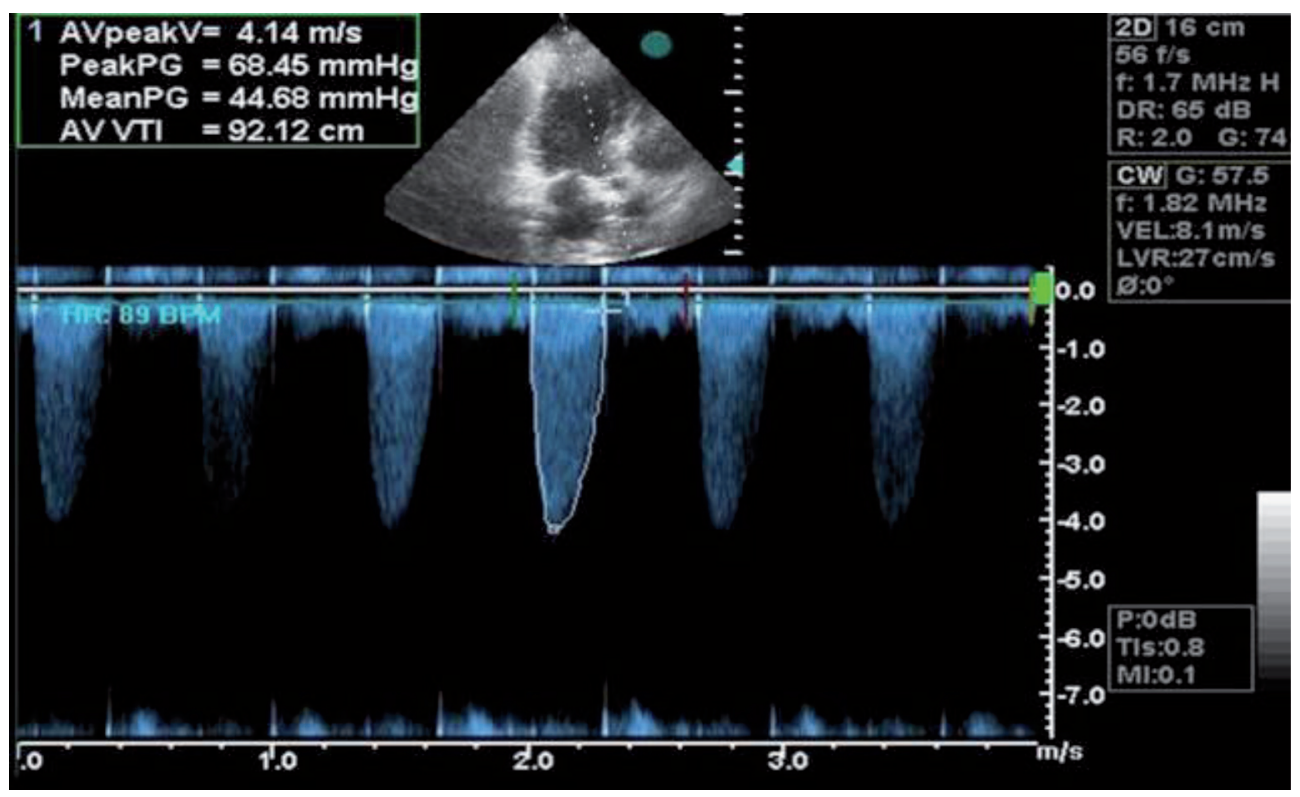

Figure2. Gradient was obtained on the aortic valve

\section{DISCUSSION}

$\mathrm{HeFH}$, with incidence of 1 in 500, is the most common known monogenic form of inherited metabolic disease. ${ }^{2}$ It is characterized by markedly elevated plasma concentrations of LDL cholesterol. HeFH patients usually have a twofold increase in total cholesterol and LDL-derived cholesterol and typically present with cardiovascular disease in their $30 \mathrm{~s}$ and $40 \mathrm{~s}$ as in our patient. If undiagnosed and untreated, the cumulative risk of CAD by age 60 years is more than $60 \%$ among men and more than $30 \%$ among women with $\mathrm{FH} .{ }^{6} \mathrm{CAD}$ is the major cause of death in $\mathrm{HeFH} .^{7}$ Excess rates of death from CAD in people with $\mathrm{HeFH}$ were highest between the ages of 20 and 39 years. Thus, HeFH was associated with a markedly increased risk of death, especially among young adults. ${ }^{8}$ In view of the markedly high LDL and total cholesterol levels, normal triglyceride level, presence of tendon xanthomata, premature coronary lesions and propable autosomal dominant inheritance (since father and brother are involved ), FH would be the most propable type of hyperlipidemia in our case. Although aortic valve involvement is rarely seen in heterozygotes our patient propably heterozygous since the mother and other siblings are not hyperlipidemic and the patient present with cardiovascular disease at the age of 34 year. Atherosclerosis affects the aortic valve as well as the aorta and coronary vessels, resulting in life threatening aortic stenosis. Aortic stenosis is critical to the prognosis for most homoFH and some HeFH patients. ${ }^{9}$ HeFH patients who require surgical replacement, show additional risk factors suh as high blood pressure, smoking, and / or diabetes mellitus which all contribute to the aggravation of aortic valvular dysfunction result from underlying hypercholesterolemia. ${ }^{10}$ Our patient did not have additional risk factory and severe aortic stenosis. The most common cause of AS is slow progressive calcific degeneration, with an asymptomatic period which can last decade's 10; therefore, it was thought that calcific AS resulted from aging and 'wear and tear' of the aortic valve.. Currently, this perception has been changing and some similarities have been found between the lesions of AS and atheromatous coronary artery disease 10 and calcific AS is being increasingly recognized as an inflammatory, atheromatous and potentially modifiable disease. The young age of the patient indicates etiologic factors other than wear and tear due to ageing processes. In conclusion $\mathrm{HeFH}$ is a treatable and important cause of early CAD and valvular lesions, thus it is important that this condition be recognized, diagnosed and treated in affected patients.

\section{REFERENCES}

1. Goldstein JL, Hobbs HH, Brown MS. Familial hypercholesterolemia. In: The Metabolic Basis of Inherited Disease. 8th 
Ed, by Scriver CR, Beaudet AL, Sly WS, Vale I, McGrawHill. New York, USA. pp 2863-2913, 2001.

2. Mabuchi H, Tatami R, Haba T, et al. Homozygous familial hypercholesterolemia in Japan. Am J Med 1978;65(2):29097

3. Cliveria F. Guidelines for the diagnosis and management of heterozygous familial hypercholesterolemia. Atherosclerosis 2004;173(1): 55-68.

4. Mabuchi H, Miyamoto S, Ueda K, et al. Causes of death in patients with familial hypercholesterolemia. Atherosclerosis 1986;61(1):1-6.

5. Rossebo AB, Pedersen TR. Hyperlipidaemia and aortic valve disease. Curr Opin Lipidol 2004; 15(4): 447-51.
6. Austin MA, Hutter CM, Zimmern RL, et al. Familial hypercholesterolemia and coronary heart disease: a HuGE association review. Am J Epidemiol 2004;160(4):421-9.

7. Miettinen TA, and Gylling H. Mortality and cholesterol metabolism in familial hypercholesterolemia. Long-term follow-up of 96 patients. Atherosclerosis 1988;8(2): 163-6.

8. George Y, Jian W, Robert A. Hegele. Heterozygous familial hypercholesterolemia: an underrecognized cause of early cardiovascular disease. CMAJ 2006;174(11):1124-9.

9. Kawaguchi A, Yutani C, and Yamamoto A: Hypercholesterolemic valvulopathy: an aspect of malignant atherosclerosis. Ther Apher Dial 2003;7(4): 439-43.

10. Weyman AE. Exploring the relationship between hyperlipidemia and aortic stenosis. Rev Cardiovasc Med 2002;3: 160-1. 